\title{
Strukturna istraživanja prionskih proteina
}

KUI - 2/2013

Prispjelo 31. listopada 2012

Prihvaćeno 20. prosinca 2012.

\author{
I. Biljan* \\ Zavod za organsku kemiju, Prirodoslovno-matematički fakultet, \\ Sveučilište u Zagrebu, Horvatovac 102A, 10000 Zagreb, Hrvatska
}

\begin{abstract}
Pogrešno nabiranje normalnog, staničnog prionskog proteina $\left(\mathrm{PrP}^{\mathrm{C}}\right)$ u patološki oblik nazvan prion $\left(\mathrm{PrP}^{\mathrm{Sc}}\right)$ povezano je s razvojem smrtonosnih neurodegenerativnih poremećaja poznatih kao prionske bolesti ili prijenosne spužvaste encefalopatije. Molekulski mehanizam kojim nastaju prioni još uvijek nije poznat te su stoga strukturna istraživanja oba oblika PrP-a vrlo važna za razjašnjavanje mehanizma pogrešnog nabiranja proteina kod prionskih bolesti. U nekim slučajevima prionske bolesti uzrokovane su mutacijama u genu koji kodira za PrP. Strukturna istraživanja mutanata PrP-a omogućuju bolje razumijevanje početnih stadija konformacijskih promjena prilikom spontanog nastajanja priona kod nasljednih oblika prionskih bolesti. $U$ ovome radu dan je pregled najvažnijih rezultata strukturnih istraživanja PrP-a s naglaskom na istraživanja provedena spektroskopijom NMR na mutantima ljudskog PrP-a.
\end{abstract}

Ključne riječi: Prionski protein, prioni, struktura, nuklearna magnetska rezonancija, mutanti

\section{Uvod}

Prionski proteini (PrP, engl. prion protein or protease-resistant protein) proteini su otporni na djelovanje proteaza, enzima koji cijepaju amidnu vezu u proteinima, pri čemu nastaju kraći peptidni fragmenti ili aminokiseline. Primarna struktura PrP-a izrazito je očuvana kod sisavaca. ${ }^{1}$ Ljudski prionski protein je glikoprotein sastavljen od 209 aminokiselina, a vezan je preko glikofosfatidilinozitolne veze na vanjsku stranu stanične membrane. lako se PrP-u pripisuje utjecaj na nekoliko procesa u središnjem živčanom sustavu, njegova točna fiziološka funkcija još uvijek nije u potpunosti razjašnjena. ${ }^{2}$ PrP je najpoznatiji zbog povezanosti sa skupinom smrtonosnih i neizlječivih neurodegenerativnih poremećaja koji pogađaju ljude i životinje, a nazivaju se prionske bolesti ili prijenosne spužvaste encefalopatije (engl. prion diseases ili transmissible spongiform encephalopathies). ${ }^{3} \mathrm{U}$ prionske bolesti čovjeka spadaju Creutzfeldt-Jakobova bolest (CJD, engl. Creutzfeldt-Jakob disease), smrtonosna obiteljska nesanica (FFI, engl. fatal familial insomnia), Gerstmann-Sträussler-Scheinkerov sindrom (GSS, engl. Gerstmann-Sträussler-Scheinker syndrome) i kuru, bolest koja se povezuje uz kanibalske obrede domorodaca Nove Gvineje. Najučestalije prionske bolesti životinja su grebež (engl. scrapie) koja se javlja kod ovâca i koza, goveđa spužvasta encefalopatija (engl. bovine spongiform encephalopathy), poznatija kao kravlje ludilo te kronična razorna bolest sobova (engl. chronic wasting disease). Većina prionskih bolesti čovjeka su sporadične, oko 10 15 \% slučajeva povezano je s mutacijama u genu koji kodira za PrP (gen PRNP, kratica od PRioN Protein), ${ }^{4}$ a u nekim slučajevima bolest se dobiva infekcijom.

Prionske bolesti nastaju zbog pretvorbe normalnog staničnog oblika prionskog proteina ( $\mathrm{Pr}^{\mathrm{C}}$, engl. normal cellular isoform) u pogrešno nabrani patološki oblik poznat pod

\footnotetext{
* Dr. sc. Ivana Biljan

e-pošta: ibiljan@chem.pmf.hr
}

nazivom prion (PrPsc, engl. scrapie isoform). ${ }^{3}$ Naziv prion predložio je 1982. godine Stanley Ben Prusiner (28. svibnja 1942., Des Moines, lowa; neurolog i biokemičar, dobitnik Nobelove nagrade za fiziologiju ili medicinu za otkriće priona, 1997. godine). Prusiner je prion definirao kao "malu proteinsku zaraznu česticu otpornu na inaktivaciju većinom postupaka koji inače modificiraju nukleinske kiseline". ${ }^{5}$ Prema toj, danas široko prihvaćenoj, "isključivo proteinskoj hipotezi" smatra se da je PrPsc jedina komponenta infektivnog patogena. Pretpostavlja se da se $\operatorname{PrP}^{\mathrm{Sc}}$ samoumnožava tako da se veže na $\operatorname{PrP}^{C}$ te zatim djeluje kao strukturni predložak koji potiče pretvorbu normalnih molekula $\mathrm{PrP}^{\mathrm{C}}$-a u patološki oblik. ${ }^{6}$

lako imaju jednaku primarnu strukturu, $\operatorname{PrPC}^{\mathrm{C}} \mathrm{PrP}^{\mathrm{Sc}}$ se razlikuju u nekoliko svojstava. Tako je FT-IR i CD spektroskopijama ustanovljeno da sekundarnu strukturu $\mathrm{PrP}^{\mathrm{C}}$-a većim dijelom čine $\alpha$-zavojnice, a PrPSc sadrži značajan udjel $\beta$-nabrane ploče (43\% u usporedbi sa $\left.3 \% \operatorname{kod} \operatorname{PrP}^{C}-a\right) .^{7,8}$ Zbog drugačijih strukturnih osobina $\operatorname{PrP}^{\mathrm{C}}$ i $\mathrm{PrP}^{\mathrm{Sc}}$ pokazuju i različita biokemijska svojstva. Dok je $\mathrm{PrP}^{\mathrm{C}}$ prisutan u monomernom obliku, topljiv u neionskim detergentima i podložan proteolizi, PrPSc je netopljiv, djelomično otporan na razgradnju proteazama te sklon agregaciji. Potonje svojstvo izrazito otežava strukturnu karakterizaciju $\mathrm{PrP}^{\mathrm{Sc}}$-a uobičajenim metodama s atomskim razlučivanjem kao što su spektroskopija NMR i difrakcija rendgenskih zraka, a koje se primjenjuju za dobivanje strukturnih informacija o samim proteinima.

Slično kao i neki drugi neurološki poremećaji, kao npr. Alzheimerova i Parkinsonova bolest, prionske bolesti često su praćene nastajanjem amiloidnog plaka u mozgu. lako se proteini koji tvore takve agregate razlikuju od bolesti do bolesti, amiloidi pokazuju slična svojstva. Nedavno provedena istraživanja pokazuju da se koncept prionskog mehanizma može primijeniti i na Alzheimerovu i na Parkinsonovu bolest, tj. da su njihovi uzročnici također infektivne proteinske molekule. ${ }^{9}$ Osnovni preduvjet za liječenje takvih neurodegenerativnih bolesti je razumijevanje mole- 
kulskog mehanizma koji uzrokuje pogrešno nabiranje proteina. Detalji nastajanja PrP ${ }^{\mathrm{Sc}}$-a kao i njegova trodimenzijska (3D) struktura visoke razlučivosti još uvijek nisu poznati. U ovom radu dan je pregled dosadašnjih stukturnih istraživanja normalnog i patološkog oblika PrP-a s naglaskom na strukturne studije provedene spektroskopijom NMR na mutantima PrP-a povezanih s nasljednim oblicima prionskih bolesti.

\section{Strukturne karakteristike prionskog proteina}

Do danas su određene 3D strukture PrP-a iz različitih vrsta sisavaca, pri čemu je većina struktura određena spektroskopijom nuklearne magnetske rezonancije (NMR) u otopini. ${ }^{10-19}$ Za dobivanje strukturnih podataka tehnikama NMR najčešće se upotrebljavaju ${ }^{15} \mathrm{~N}$ i ${ }^{13} \mathrm{C}$ izotopno obogaćeni uzorci rekombinantnih PrP-a dobiveni u povećanoj koncentraciji u genetički modificiranoj bakteriji E. coli. Određivanje strukture proteina spektroskopijom NMR provodi se na izotopno obogaćenom uzorku proteina, a prvi u nizu eksperimenata je dvodimenzijska (2D) heteronuklearna korelacijska spektroskopija NMR kojom se koreliraju ${ }^{1} \mathrm{H}$ i ${ }^{15} \mathrm{~N}$ atomi (2D ${ }^{1} \mathrm{H}-{ }^{15} \mathrm{~N}$ HSQC). Iz dobivenog ${ }^{1} \mathrm{H}-{ }^{15} \mathrm{~N}$ HSQC spektra se, iz disperzije signala, može zaključiti je li protein nabran i time prikladan za strukturnu analizu spektroskopijom NMR. Slika 1 prikazuje ${ }^{1} \mathrm{H}-{ }^{15} \mathrm{~N}$ HSQC spektar divljeg tipa ljudskog PrP-a na kojemu dobra disperzija signala ukazuje na to da je ovaj protein u nabranom stanju. Za uspješnu asignaciju kemijskih pomaka i interakcija proteina većih od 10 kDa, u čiju skupinu spada i PrP, primjenjuju se 3D heteronuklearne tehnike koje koreliraju jezgre ${ }^{1} \mathrm{H},{ }^{15} \mathrm{~N}$ i ${ }^{13} \mathrm{C} .{ }^{20}$ Primjenom 3D heteronuklearnih tehnika postiže se bolje razlučivanje i smanjuje preklapanje signala u usporedbi s homonuklearnim 2D eksperimentima. Sekvencijska asignacija kemijskih pomaka ${ }^{1} \mathrm{H},{ }^{15} \mathrm{~N}$ i ${ }^{13} \mathrm{C}$ iz okosnice proteina postiže se kombiniranjem niza heteronuklearnih 3D eksperimenata, od kojih se najčešće primjenjuju eksperimenti HNCA, HN(CO)CA, HNCACB i $\mathrm{CBCA}(\mathrm{CO}) \mathrm{NH}$. Tako npr. eksperiment HNCA korelira kemijske pomake amidnih ${ }^{1} \mathrm{H}$ i ${ }^{15} \mathrm{~N}$ s kemijskim pomakom ${ }^{13} \mathrm{C} \alpha$ istog te prethodnog aminokiselinskog ostatka, dok eksperiment $\mathrm{HN}(\mathrm{CO}) \mathrm{CA}$ daje isključivo sekvencijske povezanosti između navedenih spinova. 3D eksperimenti $\mathrm{HNCACB}$ i $\mathrm{CBCA}(\mathrm{CO}) \mathrm{NH}$ analogno koreliraju spinove ${ }^{1} \mathrm{H}$, ${ }^{15} \mathrm{~N},{ }^{13} \mathrm{C} \alpha$ i ${ }^{13} \mathrm{C} \beta$. Za asignaciju kemijskih pomaka ${ }^{1} \mathrm{H}$ i ${ }^{13} \mathrm{C}$ bočnih ogranaka najčešće se primjenjuju 3D eksperimenti ${ }^{1} \mathrm{H}-{ }^{15} \mathrm{~N}-\mathrm{TOCSY}-\mathrm{HSQC}$, (H)CC(CO)NH te $(\mathrm{H}) \mathrm{CCH}-\mathrm{TOCSY}$. 3D eksperiment ${ }^{1} \mathrm{H}-{ }^{15} \mathrm{~N}-T O C S Y-H S Q C$ daje korelaciju između kemijskih pomaka amidnih ${ }^{1} \mathrm{H}$ i ${ }^{15} \mathrm{~N}$ te kemijskih pomaka protona iz bočnog ogranka istog aminokiselinskog ostatka, dok eksperiment $(\mathrm{H}) \mathrm{CC}(\mathrm{CO}) \mathrm{NH}$ korelira kemijske pomake amidnih ${ }^{1} \mathrm{H}$ i ${ }^{15} \mathrm{~N}$ s kemijskim pomacima atoma ${ }^{13} \mathrm{C}$ iz bočnog ogranka prethodnog aminokiselinskog ostatka. 3D eksperiment (H)CCH-TOCSY korelira parove ${ }^{1} \mathrm{H} /{ }^{13} \mathrm{C}$ sa svim drugim protonima iz bočnog ogranka iste aminokiseline. Nakon asignacije atoma iz okosnice i bočnih ogranaka slijedi asignacija signala nuklearnog Overhauserova efekta (signal NOE) u $3 \mathrm{D}{ }^{1} \mathrm{H}-{ }^{15} \mathrm{~N}$ i ${ }^{1} \mathrm{H}-{ }^{13} \mathrm{C}$ NOESY-HSQC spektrima, koji predstavljaju ključne parametre za određivanje strukture proteina.

Prva trodimenzijska struktura divljeg tipa ljudskog PrP-a određena spektroskopijom NMR objavljena je 2000.

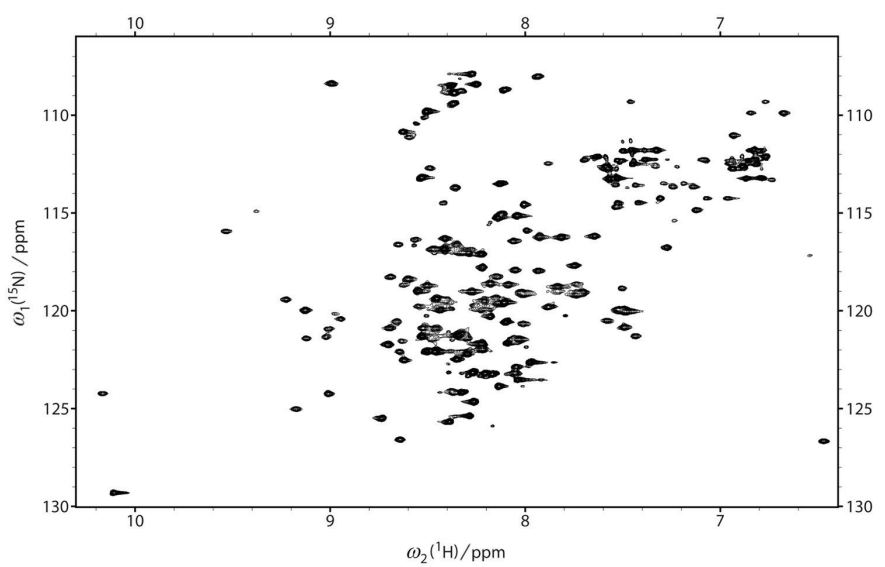

S I i k a $1-{ }^{1} \mathrm{H}_{-}{ }^{15} \mathrm{~N}$ HSQC spektar divljeg tipa ljudskog PrP-a

F i g. $1-{ }^{1} \mathrm{H}_{-}{ }^{15} \mathrm{~N}$ HSQC spectrum of the wild type human $\operatorname{PrP}$

godine. ${ }^{19}$ Ova 3D struktura ljudskog PrP-a sastoji se od dva dijela zasebnih strukturnih i dinamičkih svojstava. Prvi dio je nestrukturirana N-terminalna domena koju čine aminokiselinski ostaci 23 - 124, dok je drugi dio dobro uređena C-terminalna globularna domena sastavljena od aminokiselinskih ostataka 125 - 231. Strukturirani C-terminalni dio sadrži tri $\alpha$-zavojnice sastavljene od aminokiselinskih ostataka 144 - 154 ( $\alpha_{1}$-zavojnica), 173 - 194 ( $\alpha_{2}$-zavojnica) i 200 - 228 ( $\alpha_{3}$-zavojnica) te dva kratka antiparalelna $\beta$-lanca, koje tvore aminokiselinski ostaci 128 - $131\left(\beta_{1}\right.$-lanac) i 161 - 164 ( $\beta_{2}$-lanac) (slika 2a). Globularna domena PrP-a dodatno je stabilizirana disulfidnim mostom Cys179_ Cys214, koji premošćuje $\alpha_{2}$ i $\alpha_{3}$-zavojnicu. Strukturne karakteristike PrP-a iz drugih vrsta sisavaca vrlo su slične opisanoj strukturi ljudskog PrP-a.

Zbog otežane kristalizacije, kojoj je najvjerojatnije uzrok fleksibilnost PrP-a, difrakcija rendgenskih zraka znatno je rjeđe primjenjivana za dobivanje 3D strukturnih informacija o PrP-u u usporedbi sa spektroskopijom NMR. ${ }^{21-25}$ Ipak, kristalna struktura ljudskog PrP-a uspješno je riješena 2001. godine, te je ustanovljeno da protein kristalizira u obliku homodimera (slika 2b). ${ }^{24}$ Dimer je stabiliziran dvjema disulfidnim vezama između Cys179 i Cys214 iz različitih podjedinica. Za razliku od monomerne strukture određene NMR-om, u kristalnoj strukturi ljudskog PrP-a $\alpha_{3}$-zavojnica pakira se prema $\alpha_{2}$-zavojnici druge podjednice, a ne prema $\alpha_{2}$-zavojnici svog polipetidnog lanca, iz čega je zaključeno da u otopini postoji ravnoteža između monomernog i dimernog oblika ljudskog PrP-a, dok je u kristalu isključivo prisutan dimer.

Za razliku od normalnog oblika $\mathrm{PrP}^{\mathrm{C}}$-a, 3D struktura patološkog $\mathrm{PrPSc}^{\mathrm{S}}$-a još uvijek nije riješena. Ipak, na temelju rezultata dobivenih primjenom biofizikalnih tehnika niskog razlučivanja predloženo je nekoliko modela. Jedan od najpopularnijih strukturnih modela $\mathrm{PrP}^{\mathrm{Sc}}-\mathrm{a}$, predložen na temelju podataka dobivenih elektronskom mikroskopijom, jest $\beta$-zavojnica. ${ }^{26} \mathrm{U}$ tom modelu osnovnu simetričnu jedinicu PrPSc-a čini trimer u kojem aminokiselinski ostaci iz $\mathrm{N}$-terminalne domene $(\approx 90-175)$ tvore lijevu $\beta$-zavojnicu, dok C-terminalno područje (aminokiselinski ostaci 178 230) uglavnom zadržava sekundarnu strukturu $\alpha$-zavojnice kao u $\mathrm{PrP}^{\mathrm{C}}-\mathrm{u}$. Veći agregati nastaju vertikalnim slaganjem trimera PrP-a uzduž osi $\beta$-zavojnice. Takozvani spiralni model predložen je na temelju simulacija molekulskom 

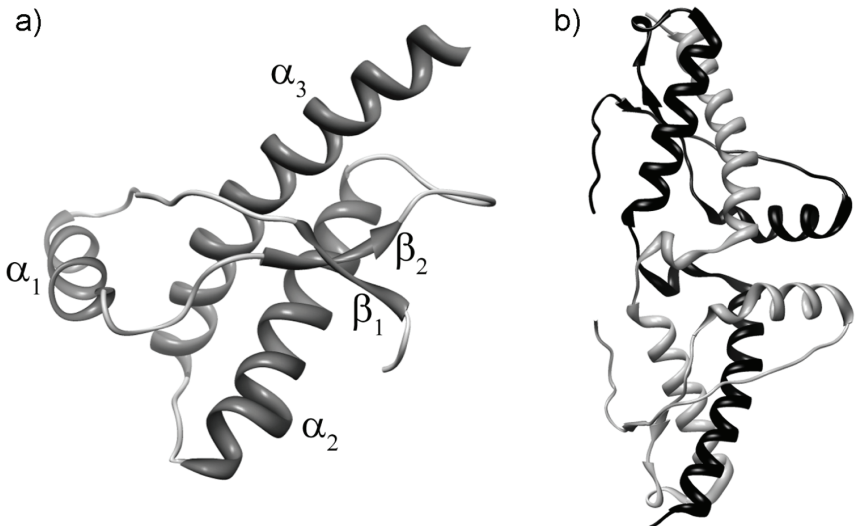

Slika 2 - 3D strukture C-terminalne domene ljudskog PrP-a dobivene a) spektroskopijom NMR u otopini (PDB kod 1QM1) ${ }^{19} i$ b) difrakcijom rendgenskih zraka (PDB kod 1/4M) ${ }^{24}$

F i g. $2-3 D$ structures of the C-terminal domain of human $\operatorname{Pr} P$ determined by a) NMR spectroscopy in solution (PDB code $1 Q M 1)^{19}$ and b) X-ray diffraction (PDB code $\left.1 / 4 M\right)^{24}$

dinamikom pri amiloidoznim uvjetima (niskim vrijednostima $\mathrm{pH}$ ) upotrebljavajući kao polaznu točku prirodnu strukturu PrP-a. ${ }^{27}$ Spiralni model sastoji se od spiralne jezgre proširenih ploča koje čine $\beta$-lanci sastavljeni od aminokiselinskih ostataka 116-119, 129-132, 135-140 i $160-164$. Slično kao i kod modela $\beta$-zavojnice, u stvaranju $\beta$-lanaca sudjeluju aminokiselinski ostaci iz $\mathrm{N}$-terminalnog dijela, dok većina C-terminalnog dijela PrP-a ostaje nepromijenjena. U posljednjem modelu, predloženom na temelju strukturnih podataka dobivenih tehnikom izmjene vodik/deuterij u sprezi s masenom spektrometrijom, $\mathrm{PrPsc}$ se prikazuje kao slagalina paralelnih $\beta$-nabranih ploča. ${ }^{28} \mathrm{U}$ tom je modelu $\mathrm{PrP}^{\mathrm{sc}}$ sastavljen od $\beta$-lanaca i relativno kratkih zavoja ili petlji bez prisustva $\alpha$-zavojnica, po čemu se značajno razlikuje od prethodna dva modela. Budući da su sva tri modela predložena na temelju biofizikalnih metoda niskog razlučivanja, teško je odrediti koji je od njih najbliži stvarnoj strukturi PrPsc-a.

\section{NMR strukture mutanata prionskog proteina}

Jedan od najčvršćih argumenata "isključivo-proteinskog" modela veza je između nasljednih prionskih bolesti i mutacija u genu PRNP. Do sada je identificirano 55 patoloških mutacija, pri čemu su genetski oblici prionskih bolesti povezani s njih 37 (slika 3). ${ }^{4}$ Mehanizam kojim patološke mutacije uzrokuju bolest još uvijek nije razjašnjen. Postoji nekoliko načina na koje mutacije mogu izazvati spontano stvaranje PrPsc-a u mozgu. Pokazalo se da neke mutacije utječu na termodinamičku stabilnost $\operatorname{PrPC}_{-}$a, te na taj način povećavaju vjerojatnost njegove pretvorbe u patološki oblik. ${ }^{29-31}$ Osim utjecaja na stabilnost, mutacije mogu promijeniti i površinska svojstva $\operatorname{PrP}_{-}$a, te tako prouzrokovati neočekivane interakcije $s$ drugim molekulama koje sudjeluju u patološkoj pretvorbi. ${ }^{32,33}$

Čak 30 od ukupno 37 patoloških mutacija smješteno je u globularnoj domeni $\mathrm{PrPC}^{\mathrm{C}}$ a, što omogućava strukturnu karakterizaciju varijanti ljudskog $\operatorname{PrP}^{\mathrm{C}}$-a, a time i otkrivanje dijelova strukture koji bi mogli igrati važnu ulogu u ranim stadijima spontanog nastanka priona kod nasljednih prionskih bolesti. Spektroskopijom NMR u otopini do sada su određene strukture visoke razlučivosti rekombinantnog ljudskog PrP-a s mutacijama E200K, ${ }^{34}$ Q212P ${ }^{35}$ i V210l. ${ }^{36}$ Mutacije E200K i V210I odgovorne su za Creutzfeldt-Jakobovu bolest koja je najučestaliji oblik nasljednjih prionskih bolesti, dok mutacija Q212P uzrokuje Gerstmann-Sträussler-Scheinkerov sindrom.

3D strukture mutanata E200K, Q212P i V210I PrP-a posjeduju vrlo sličnu opću strukturu kao i divlji tip ljudskog PrPa, sastavljenu od nestrukturiranog $\mathrm{N}$-terminalnog dijela $\mathrm{i}$ C-terminalne globularne domene. C-terminalni dio sadrži tri $\alpha$-zavojnice $\left(\alpha_{1}, \alpha_{2}\right.$ i $\left.\alpha_{3}\right)$ te jednu vrlo kratku $\beta$-nabranu ploču koju tvore antiparalelni $\beta_{1}$ i $\beta_{2}$ lanci. Zavojnice $\alpha_{2}$ i $\alpha_{3}$ povezane su disulfidnim mostom preko Cys179 i Cys214.

Ustanovljeno je da zamjena glutaminske kiseline lizinom u mutantu E200K ne izaziva značajne strukturne promjene PrP-a, ali mijenja raspodjelu naboja na površini proteina. $U$ ljudskom PrP-u površina oko Glu200 karakterizirana je uglavnom negativnim električnim potencijalom pri neutralnim vrijednostima $\mathrm{pH}$ odnosno područjima negativnog $\mathrm{i}$ pozitivnog električnog potencijala pri blago kiselim uvjetima. S druge strane, u mutantu E200K površina proteina uglavnom je pozitivno nabijena i pri neutralnim i blago kiselim uvjetima. Promjene u raspodjeli naboja na površini mutanta E200K PrP-a vjerojatno utječu na interakcije s drugim molekulama koje također sudjeluju u patološkoj pretvorbi, te je na taj način olakšan spontani nastanak priona kod Creutzfeldt-Jakobove bolesti izazvane mutacijom na

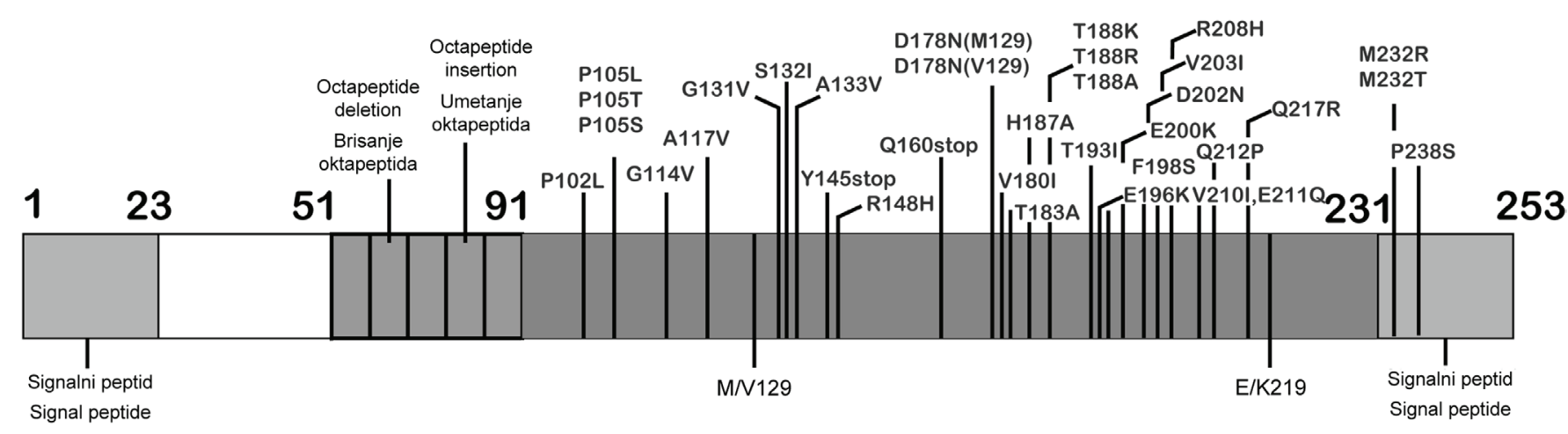

S I i k a 3 - Ljudski gen PRNP sa svim do sada identificiranim mutacijama. ${ }^{4}$ Zreli PrP sastavljen je od aminokiselinskih ostataka 23 - 231 , N-terminalnog signalnog peptida (1 - 22) i C-terminalnog signalnog peptida (232 - 253).

F i g. 3 - Human PRNP gene with all currently identified mutations. ${ }^{4}$ Mature PrP consists of residues 23-231, N-terminal signal peptide (1-22) and C-terminal signal peptide (232-253). 
kodonu 200. Kao mogući kofaktori patološke pretvorbe PrP-a identificirane su molekule ribonukleinske kiseline (RNA), proteoglikani te lipidi, no mehanizam njihova djelovanja još uvijek nije razjašnjen. ${ }^{37-39}$

Suprotno mutaciji E200K, mutacije Q212P i V210l uzrokuju značajne lokalne strukturne promjene u ljudskom PrP-u. Zamjena glutamina prolinom u mutantu Q212P dovodi do prijeloma $\alpha_{3}$-zavojnice na dvije zavojnice, $\alpha_{3} \mathrm{i}$ $\alpha_{4}$ (slika 4). Naime, $\alpha_{3}$-zavojnica je u mutantu Q212P dobro uređena između Glu200 i Arg220, dok sljedeća dva aminokiselinska ostatka Glu221 i Ser222 ometaju njezinu pravilnu strukturu. Zbog prijeloma $\alpha_{3}$-zavojnice dolazi do promjena $u$ hidrofobnim interakcijama između C-terminalnog kraja $\alpha_{3}$-zavojnice i $\beta_{2}$ - $\alpha_{2}$-petlje, što se očituje većim udaljenostima između tih dvaju sekundarnih strukturnih elemenata te većoj izloženosti hidrofobnih aminokiselina otapalu.

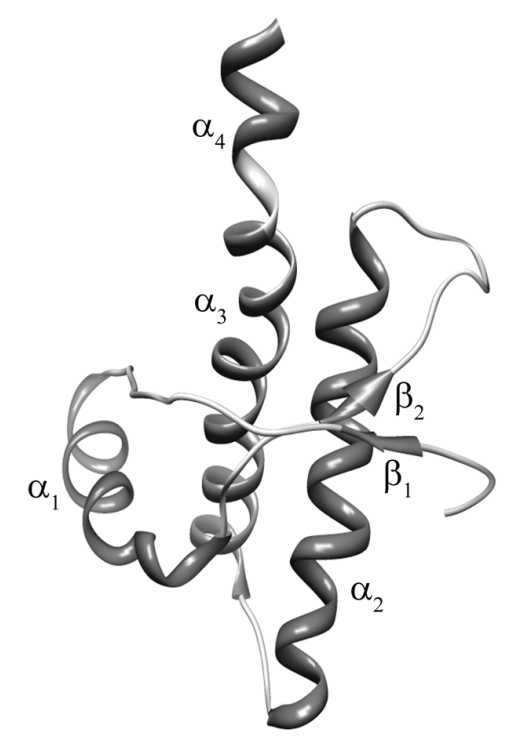

S I ik a 4 - NMR struktura ljudskog PrP-a s mutacijom Q212P (PDB kod 2KUN) $)^{35}$

F i g. 4 - NMR structure of human PrP with Q212P mutation $(P D B \text { code } 2 K U N)^{35}$

Usporedbom strukture određene NMR spektroskopijom divljeg tipa ljudskog PrP-a sa strukturom mutanta V210I mogu se uočiti određene strukturne promjene. Val210 smješten je u sredini $\alpha_{3}$-zavojnice i dio je gusto pakirane jezgre aminokiselina s hidrofobnim bočnim ograncima. Taj dio globularne domene igra iznimno važnu ulogu u ukupnoj stabilnosti $\operatorname{PrP}^{\mathrm{C}}$-a. Iz strukturnih podataka dobivenih spektroskopijom NMR opaža se da zamjena valina robusnijim izoleucinom, zbog steričkih smetnji, uzrokuje preraspodjelu hidrofobnih interakcija između aminokiselinskih ostataka $\alpha_{2}$ - i $\alpha_{3}$-zavojnica (slika 5a). Također, mutacija V210I utječe na konformaciju $\beta_{2}-\alpha_{2}$-petlje i njene dugosežne tercijarne interakcije s aminokiselinskim ostacima iz C-terminalnog kraja $\alpha_{3}$-zavojnice (slika 5b). Slično kao kod mutanta Q212P, potonje strukturne promjene u mutantu V210l dovode do veće izloženosti hidrofobne površine proteina otapalu.

Uz patološke mutacije koje se povezuju s nasljednim prionskim bolestima, u genu PRNP identificirani su i polimor-

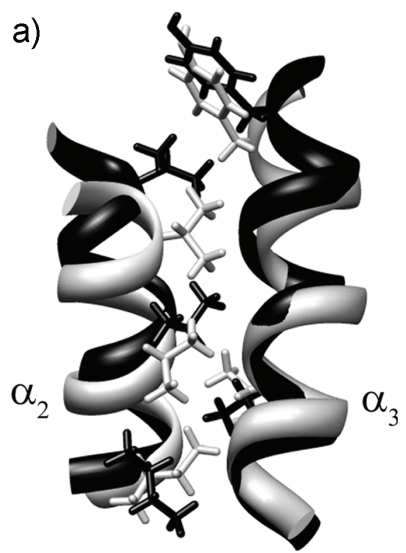

b)

S I i k a 5 - Usporedba strukturnih karakteristika ljudskog PrP-a s mutacijom V210I (crno, PDB kod 2LEJ) ${ }^{36}$ i divljeg tipa ljudskog PrP-a (sivo, PDB kod 1QM1). ${ }^{19}$ a) Hidrofobne interakcije između aminokiselinskih ostataka iz $\alpha_{2^{-}} i \alpha_{3}$-zavojnice. b) $\pi$ - $\pi$ interakcije na međupovršini $\beta_{2}$ - $\alpha_{2}$-petlje i C-terminalnog dijela $\alpha_{3}$-zavojnice.

F i g. 5 - Comparison of structural features of human $\operatorname{Pr} P$ with V210l mutation (in black, PDB code 2LEJ) ${ }^{36}$ and wild type human $\operatorname{PrP}$ (in grey, $P D B$ code 1QM1). ${ }^{19}$ a) Hydrophobic interactions between residues in $\alpha_{2}$ - and $\alpha_{3}$-helices. b) $\pi$ - $\pi$ interactions at the interface of the $\beta_{2}-\alpha_{2}$ loop and the C-terminal part of $\alpha_{3}$-helix.

fizmi koji utječu na etiologiju i neuropatologiju prionskih bolesti. Jedan je od intenzivnije istraživanih polimorfizam M129V, koji na kodonu 129 sadrži ili metionin ili valin. Polimorfizam M129V utječe na podložnost sporadičnim i infektivnim oblicima prionskih bolesti, pri čemu su homozigoti za metionin skloniji obolijevanju. ${ }^{40}$ Drugi važan polimorfizam ljudskog PrP-a jest polimorfizam E219K, za koji je ustanovljeno da štiti od sporadične Creutzfeldt-Jakobove bolesti. ${ }^{41}$ Nedavno je na temelju podataka dobivenih spektroskopijom NMR određena 3D struktura rekombinantnog ljudskog PrP-a s polimorfizmom E219K. ${ }^{42} \mathrm{U}$ usporedbi sa strukturama patoloških mutanata Q212P i V210l, struktura ljudskog PrP-a s polimorfizmom E219K ne ukazuje na ometanje aromatskih i hidrofobnih interakcija među aminokiselinskim ostacima iz C-terminalnog dijela $\alpha_{3}$-zavojnice i $\beta_{2}-\alpha_{2}$-petlje. Međutim, zamjena glutaminske kiseline lizinom na kodonu 219 znatno utječe na raspodjelu naboja na površini proteina. Promjene su najuočljivije oko mjesta same zamjene, zatim na međupovršini $\beta_{2}-\alpha_{2}$-petlje i C-terminalnog kraja $\alpha_{3}$-zavojnice te na $\mathrm{N}$-terminalnom dijelu $\alpha_{3}$-zavojnice. Dok su nabrojana područja uglavnom neutralna ili negativno nabijena u divljem tipu ljudskog PrP-a, kod PrP-a s polimorfizmom E219K ona su pozitivno nabijena.

Poseban interes $\mathrm{u}$ biologiji priona usmjeren je na epitop koji čine $\beta_{2}-\alpha_{2}$-petlja te C-terminalni kraj $\alpha_{3}$-zavojnice. Naime, već u ranijim istraživanjima to je područje smatrano mjestom interakcije s hipotetskim kofaktorom koji sudjeluje u stvaranju priona. ${ }^{32,33}$ Opaženo je da konformacija same $\beta_{2}-\alpha_{2}$-petlje te njezine interakcije s C-terminalnim dijelom $\alpha_{3}$-zavojnice igraju ulogu u transmisiji priona i podložnosti bolesti. Sisavci čiji PrP posjeduje fleksibilnu $\beta_{2}-\alpha_{2}$-petlju lako se mogu zaraziti prionima, dok se prioni slabo prenose kod vrsta sa strukturno dobro definiranom $\beta_{2}-\alpha_{2}$-petljom. ${ }^{11,13,16,17,43}$ Istraživanja patoloških mutanata Q212P i V210I spektroskopijom NMR ukazuju na to da u usporedbi s divljim tipom PrP-a te PrP-a sa zaštitnim polimorfizmom E219K, mutacije uzrokuju gubitak tercijarnih 
a)

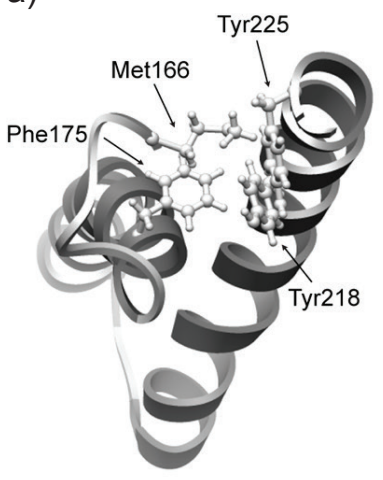

b)

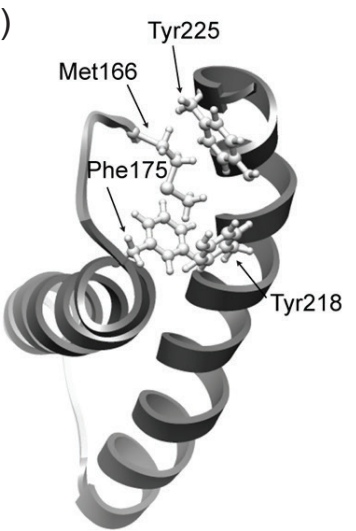

c)

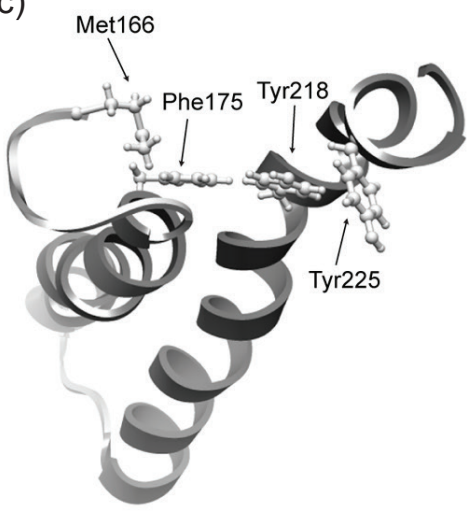

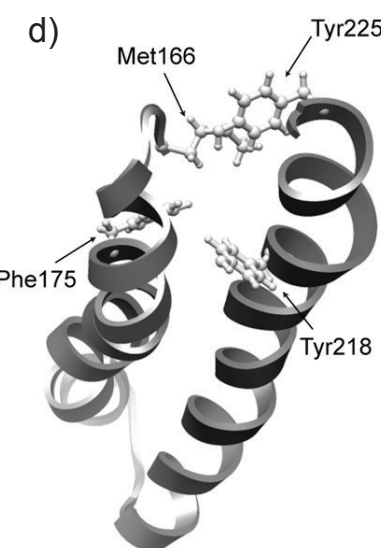

SI i k a 6 - Interakcije na međupovršini $\beta_{2}$ - $\alpha_{2}$-petlje i C-terminusa $\alpha_{3}$-zavojnice kod a) ljudskog PrP-a s polimorfizmom E219K (PDB kod $2 L F T),{ }^{42}$ b) divljeg tipa ljudskog PrP-a (PDB kod 2LSB), ${ }^{42}$ c) ljudskog PrP-a s mutacijom Q212P (PDB kod 2KUN) ${ }^{35}$ i d) ljudskog PrP-a s mutacijom V210l (PDB kod 2LE) $)^{36}$

F i g. 6 - Interactions at the interface of the $\beta_{2}-\alpha_{2}$ loop and the C-terminus of the $\alpha_{3}$-helix in a) human PrP with E219K polymorphism (PDB code 2LFT) ${ }^{42}$ b) wild type human PrP $(P D B$ code $2 L S B){ }^{42}$ c) human PrP with Q212P mutation (PDB code $\left.2 K U N\right)^{35}$ and d) human PrP with V210l mutation (PDB code $2 L E J)^{36}$

a)
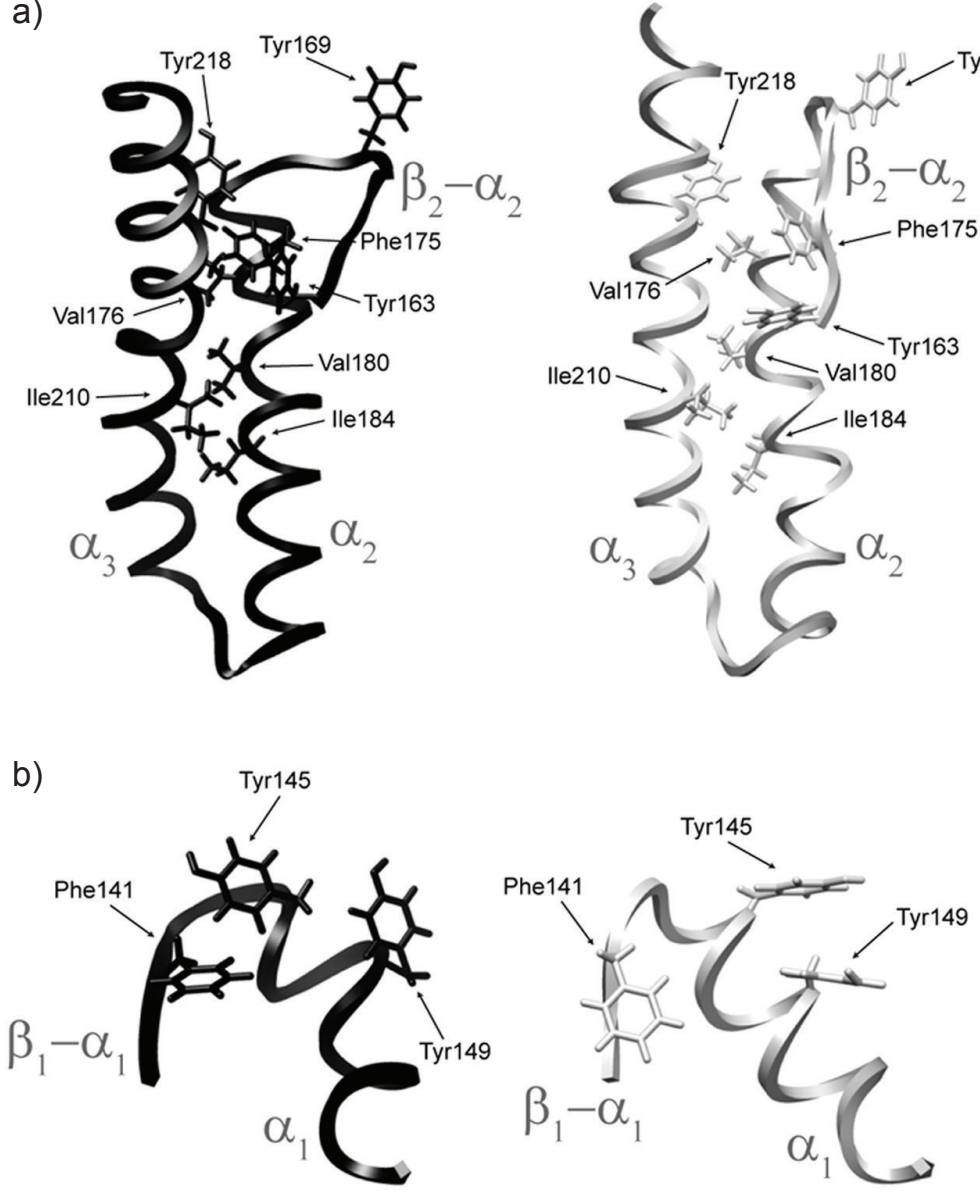

SI i k a 7 - Usporedba struktura ljudskog PrP-a određenih spektroskopijom NMR s mutacijom V210l pri $\mathrm{pH}=7,2$ (crno, PDB kod 2LV1) ${ }^{55} \mathrm{i} \mathrm{pH}=5,5$ (sivo, PDB kod 2LEJ). ${ }^{36}$ a) Hidrofobne interakcije između aminokiselinskih ostataka iz $\alpha_{2}-i \alpha_{3}$-zavojnice te $\beta_{2}$ - $\alpha_{2}$-petlje. b) $\pi$ - $\pi$ interakcije na međupovršini $\beta_{1}$ - $\alpha_{1}$-petlje i $\alpha_{1}$-zavojnice.

F i g. 7 - Comparison of NMR structures of human PrP with V210I mutation at $\mathrm{pH}=7,2$ (in black, $P D B$ code $2 L V 1)^{55}$ and $p H=5,5$ (in grey, $P D B$ code 2 LEJ). ${ }^{36}$ a) Hydrophobic interactions between residues from the $\alpha_{2}$ - and $\alpha_{3}$-helices and the $\beta_{2}-\alpha_{2}$ loop. b) $\pi$ - $\pi$ interactions at the interface of the $\beta_{1}-\alpha_{1}$ loop and $\alpha_{1}$-helix. kontakata između aminokiselinskih ostataka iz $\beta_{2}$ - $\alpha_{2}$-petlje (npr. Met166 i Phe175) i $\alpha_{3}$-zavojnice (npr. Tyr218 i Tyr225) (slika 6), što pak rezultira većom izloženosti hidrofobnih aminokiselina otapalu. Slično je opaženo i u strukturi mutanta E200K određenoj NMR spektroskopijom, ${ }^{34}$ kristalnim strukturama mutanata F198S i $\mathrm{D} 178 \mathrm{~N}^{25}$ te $\mathrm{u}$ istraživanjima provedenim molekulskom dinamikom. ${ }^{44-46}$ Izloženost hidrofobnih aminokiselina otapalu u patološkim mutantima može povećati njihovu sklonost specifičnim intermolekulskim interakcijama koje dovode do spontanog nastanka priona u nasljednim prionskim bolestima.

\section{Utjecaj pH na strukturu prionskog proteina}

Substanično mjesto na kojem se odvija pretvorba normalnog $\mathrm{PrPC}^{\mathrm{C}}$-a u patološki $\mathrm{PrP}^{\mathrm{Sc}}$ još je jedna zagonetka vezana uz prione. Pretpostavlja se da se taj proces odvija ili u endosomima gdje je $\mathrm{pH}$ između 4,7 i 6,5 ili na površini stanice gdje je $\mathrm{pH} \approx 7 .{ }^{47}$ Prijašnja istraživanja su pokazala da smanjenje vrijednosti $\mathrm{pH}$ uzrokuje konformacijske promjene PrP-a i to već pri blago kiselim uvjetima sugerirajući da su endosomi vjerojatnije mjesto patološke pretvorbe. ${ }^{48-54}$ Međutim ova saznanja temeljena su uglavnom na rezultatima dobivenim simulacijama molekulskom dinamikom, dok je u literaturi vrlo malo podataka o eksperimentalnim istraživanjima strukturnih svojstava $\mathrm{PrPC}^{\mathrm{C}}$-a s atomskim razlučivanjem pri pH koji odgovara onom na površini stanice i unutar endosoma. Naime, većina spektroskopijom NMR određenih struktura PrP-a dobivena je eksperimentima pri blago kiselim uvjetima $(\mathrm{pH}=4,5$ ili 5,5), dok su pri neutralnim uvjetima spektroskopijom NMR do sada određene samo strukture divljeg 
tipa ljudskog PrP-a (pri $\mathrm{pH}=7)^{49}$ te nedavno PrP-a s patološkom mutacijom V210I (pri $\mathrm{pH}=7,2$ ). ${ }^{55}$ 3D struktura divljeg tipa PrP-a pri $\mathrm{pH}=7$ vrlo je slična strukturi istog proteina određenoj ranije pri $=\mathrm{pH} 4,5$. Razlike se opažaju na C-terminalnim krajevima $\alpha_{1}$ - i $\alpha_{2}$-zavojnica, koji pokazuju bolju uređenost pri $\mathrm{pH}=7 \mathrm{u}$ usporedbi s $\mathrm{pH}=4,5$. Uz to, globularna domena divljeg tipa ljudskog PrP-a je termodinamički stabilnija pri neutralnom pH sugerirajući da do patološke pretvorbe dolazi pri kiselim uvjetima. Kod PrP-a s mutacijom V210I također se mogu opaziti značajne strukturne različitosti s promjenom $\mathrm{pH}$ od 5,5 do 7,2 . U mutantu $\mathrm{V} 210 \mathrm{I}$ najizraženije su $\mathrm{pH}$-ovisne promjene lokalizirane u području između $\alpha_{2}$ - i $\alpha_{3}$-zavojnica, na međupovršinama $\beta_{2}-\alpha_{2}$-petlje i $\alpha_{3}$-zavojnice te $\beta_{1}$ - $\alpha_{1}$-petlje i $\alpha_{1}$-zavojnice (slika 7). Naime, tercijarni kontakti među aminokiselinskim ostacima iz navedenih sekundarnih strukturnih elemenata u mutantu $\mathrm{V} 210 \mathrm{I}$ manje su narušeni pri $\mathrm{pH}=$ 7,2 nego pri $\mathrm{pH}=5,5$. Takvi rezultati ukazuju na veću strukturnu stabilnost mutanta V210I pri neutralnim uvjetima te sugeriraju da je spontani nastanak priona kod nasljednjih prionskih bolesti skloniji pri kiselim uvjetima koji vladaju unutar endosoma.

\section{Zaključak}

Prionske bolesti pripadaju skupini neurodegenerativnih poremećaja uzrokovanih pogrešnim nabiranjem PrP-a. Strukturna istraživanja PrP-a tehnikama visokog razlučivanja kao što je spektroskopija NMR nužna su za razumijevanje molekulskog mehanizma pretvorbe normalnog PrP-a u patološki oblik. Jedan od načina za bolje razumijevanje početnih stadija konformacijskih promjena koje vode do nastanka priona strukturna su istraživanja spektroskopijom NMR mutanata ljudskog PrP-a povezanih s nasljednim oblicima prionskih bolesti. Rezultati tako provedenih istraživanja na nekoliko patoloških mutanata PrP-a omogućili su otkrivanje područja na kojima najvjerojatnije započinje patološka pretvorba. Ustanovljeno je da patološke mutacije ne mijenjaju opću strukturu ljudskog PrP-a koju čini neuređena $\mathrm{N}$-terminalna domena te globularni C-terminalni dio sastavljen od tri $\alpha$-zavojnice te dva kratka antiparalelna $\beta$-lanca. Međutim mutacije utječu na lokalne strukturne karakteristike PrP-a. Najizraženije promjene opažene su $u$ hidrofobnim interakcijama između $\beta_{2}-\alpha_{2}$-petlje i C-terminalne $\alpha_{3}$-zavojnice odnosno između $\alpha_{2^{-}}$i $\alpha_{3}$-zavojnice. Dok su kod patoloških mutanata interakcije između navedenih sekundarnih strukturnih elemenata oslabljene u usporedbi s divljim tipom ljudskog PrP-a što naposljetku dovodi do veće izloženosti hidrofobnih aminokiselina otapalu, kod PrP-a sa zaštitnim polimorfizmom E219K nisu uočene slične strukturne promjene. Nadalje, izučavanja strukturnih promjena spektroskopijom NMR divljeg tipa ljudskog PrP-a te mutanta V210l u ovisnosti o pH pokazala su da su oba proteina strukturno stabilnija pri neutralnim uvjetima odnosno da do nastanka priona najvjerojatnije dolazi pri blago kiselim uvjetima prisutnim unutar endosoma. Daleko najvažniji cilj u istraživanju priona određivanje je 3D strukture patološkog $\operatorname{PrP}^{\mathrm{Sc}}$-a, no do danas ista još uvijek nije poznata. Unatoč tome spoznaje dobivene dosadašnjim strukturnim istraživanjima PrP-a važan su doprinos za razumijevanje molekulskog mehanizma prionskih bolesti te za razvoj djelotvornih antiprionskih lijekova.

\section{ZAHVALA}

Autorica se posebno zahvaljuje prof. Janezu Plavecu te Gregoru Ilcu s Kemijskog inštituta u Ljubljani, Slovenija na mnogobrojnim poticajnim i korisnim diskusijama.

\section{Popis simbola i kratica \\ List of symbols and abbreviations}

$\omega \quad-$ kemijski pomak, ppm

- chemical shift, ppm

CD - cirkularni dikroizam

- circular dichroism

FT-IR - Fourierova transformirajuća infracrvena spektroskopija

- Fourier transformed infrared spectroscopy

HSQC - heteronuklearna korelacija u kojoj se primjenjuje koherencija od jednog kvanta

- heteronuclear single quantum correlation

NMR - nuklearna magnetska rezonancija

- nuclear magnetic resonance

NOE - nuklearni Overhauserov efekt

- nuclear Overhauser effect

NOESY - spektroskopija nuklearnog Overhauserovog efekta

- nuclear Overhauser enhancement spectroscopy

PrP - prionski protein

- prion protein or protease-resistant protein

$\mathrm{PrP}^{\mathrm{C}}$ - stanični prionski protein

- cellular prion protein

$\mathrm{PrPSc}$ - patološki ili "scrapie" prionski protein

- pathological or "scrapie" prion protein

PRNP - gen koji kodira za prionski protein

- gene coding for prion protein

PDB - proteinska banka podataka

- protein data bank

RNA - ribonukleinska kiselina

- ribonucleic acid

TOCSY - totalna korelacijska spektroskopija

- total correlation spectroscopy

\section{Literatura \\ References}

1. F. Wopfner, G. Weidenhofer, R. Schneider, A. von Brunn, S. Gilch, T. F. Schwarz, T. Werner, H. M. Schatzl, Analysis of 27 mammalian and 9 avian PrPs reveals high conservation of flexible regions of the prion protein, J. Mol. Biol. 289 (1999) 1163-1178.

2. A. Aguzzi, F. Baumann, J. Bremer, The prion's elusive reason for being, Annu. Rev. Neurosci. 31 (2008) 439-477.

3. S. B. Prusiner, Prions, Proc. Natl. Acad. Sci. USA 95 (1998) 13363-13383.

4. G. G. Kovacs, G. Trabattoni, J. A. Hainfellner, J. W. Ironside, R. S. Knight, H. Budka, Mutations of the prion protein gene phenotypic spectrum, J. Neurol. 249 (2002) 1567-1582.

5. S. B. Prusiner, Novel proteinaceous infectious particles cause scrapie, Science 216 (1982) 136-144.

6. N. J. Cobb, W. K. Surewicz, Prion Diseases and Their Biochemical Mechanisms, Biochemistry 48 (2009) 2574-2585.

7. B. W. Caughey, A. Dong, K. S. Bhat, D. Ernst, S. F. Hayes, W. S. Caughey, Secondary structure analysis of the scrapie-associa- 
ted protein PrP 27-30 in water by infrared spectroscopy, Biochemistry 30 (1991) 7672-7680.

8. K. M. Pan, M. Baldwin, J. Nguyen, M. Gasset, A. Serban, D. Groth, I. Mehlhorn, Z. Huang, R. J. Fletterick, F. E. Cohen, Conversion of alpha-helices into beta-sheets features in the formation of the scrapie prion proteins, Proc. Natl. Acad. Sci. USA 90 (1993) 10962-10966.

9. S. B. Prusiner, A unifying role for prions in neurodegenerative disorders, Science 336 (2012) 1511-1513.

10. L. Calzolai, D. A. Lysek, P. Guntert, C. von Schroetter, R. Riek, R. Zahn, K. Wuthrich, NMR structures of three single-residue variants of the human prion protein, Proc. Natl. Acad. Sci. USA 97 (2000) 8340-8345.

11. B. Christen, D. R. Perez, S. Hornemann, K. Wuthrich, NMR structure of the bank vole prion protein at 20 degrees $C$ contains a structured loop of residues 165-171, J. Mol. Biol. 383 (2008) 306-312.

12. D. G. Donne J. H. Viles, D. Groth, I. Mehlhorn, T. L. James, F. E. Cohen, S. B. Prusiner, P. E. Wright, H. J. Dyson, Structure of the recombinant full-length hamster prion protein $\operatorname{PrP}(29-$ 231): The $N$ terminus is highly flexible, Proc. Natl. Acad. Sci. USA 94 (1997) 13452-13457.

13. A. D. Gossert, S. Bonjour, D. A. Lysek, F. Fiorito, K. Wuthrich, Prion protein NMR structures of elk and of mouse/elk hybrids, Proc. Natl. Acad. Sci. USA 102 (2005) 646-650.

14. T. L. James, H. Liu, N. B. Ulyanov, S. Farr-Jones, H. Zhang, D. G. Donne, K. Kaneko, D. Groth, I. Mehlhorn, S. B. Prusiner, F. E. Cohen, Solution structure of a 142-residue recombinant prion protein corresponding to the infectious fragment of the scrapie isoform, Proc. Natl. Acad. Sci. USA 94 (1997) 1008610091.

15. F. Lopez Garcia, R. Zahn, R. Riek, K. Wuthrich, NMR structure of the bovine prion protein, Proc. Natl. Acad. Sci. USA 97 (2000) 8334-8339.

16. D. R. Perez, F. F. Damberger, K. Wuthrich, Horse prion protein NMR structure and comparisons with related variants of the mouse prion protein, J. Mol. Biol. 400 (2010) 121-128.

17. Y. Wen, J. Li, W. Yao, M. Xiong, J. Hong, Y. Peng, G. Xiao, D. Lin, Unique structural characteristics of the rabbit prion protein, J. Biol. Chem. 285 (2010) 31682-31693.

18. R. Riek, S. Hornemann, G. Wider, M. Billeter, R. Glockshuber, K. Wuthrich, NMR structure of the mouse prion protein domain PrP(121-231), Nature 382 (1996) 180-182.

19. R. Zahn, A. Liu, T. Luhrs, R. Riek, C. von Schroetter, F. Lopez Garcia, M. Billeter, L. Calzolai, G. Wider, K. Wuthrich, NMR solution structure of the human prion protein, Proc. Natl. Acad. Sci. USA 97 (2000) 145-150.

20. J. Cavanagh, W. F. Fairbrother, A. G. Palmer, M. Rance, N. J. Skelton, Protein NMR spectroscopy: Principles and practice. Elsevier Inc, 2007.

21. S. V. Antonyuk, C. R. Trevitt, R. W. Strange, G. S. Jackson, D. Sangar, M. Batchelor, S. Cooper, C. Fraser, S. Jones, T. Georgiou, A. Khalili-Shirazi, A. R. Clarke, S. S. Hasnain, J. Collinge, Crystal structure of human prion protein bound to a therapeutic antibody, Proc. Natl. Acad. Sci. USA 106 (2009) 25542558.

22. F. Eghiaian, J. Grosclaude, S. Lesceu, P. Debey, B. Doublet, E. Treguer, H. Rezaei, M. Knossow, Insight into the PrPC $\rightarrow$ PrPSC conversion from the structures of antibody-bound ovine prion scrapie-susceptibility variants, Proc. Natl. Acad. Sci. USA 101 (2004) 10254-10259.

23. L. F. Haire, S. M. Whyte, N. Vasisht, A. C. Gill, C. Verma, E. J. Dodson, G. G. Dodson, P. M. Bayley, The crystal structure of the globular domain of sheep prion protein, J. Mol. Biol. 336 (2004) 1175-1183.

24. K. J. Knaus, M. Morillas, W. Swietnicki, M. Malone, W. K. Surewicz, V. C. Yee, Crystal structure of the human prion pro- tein reveals a mechanism for oligomerization, Nat. Struct. Biol. 8 (2001) 770-774.

25. S. Lee, L. Antony, R. Hartmann, K. J. Knaus, K. Surewicz, W. K. Surewicz, V. C. Yee, Conformational diversity in prion protein variants influences intermolecular beta-sheet formation, EMBO J. 29 (2010) 251-262.

26. C. Govaerts, H. Wille, S. B. Prusiner, F. E. Cohen, Evidence for assembly of prions with left-handed beta-helices into trimers, Proc. Natl. Acad. Sci. USA 101 (2004) 8342-8347.

27. M. L. DeMarco, V. Daggett, From conversion to aggregation: protofibril formation of the prion protein, Proc. Natl. Acad. Sci. USA (2004) 2293-2298.

28. N. J. Cobb, F. D. Sonnichsen, H. McHaourab, W. K. Surewicz, Molecular architecture of human prion protein amyloid: a parallel, in-register $\beta$-structure, Proc. Natl. Acad. Sci. USA 104 (2007) 18946-18951.

29. A. C. Apetri, K. Surewicz, W. K. Surewicz, The effect of disease-associated mutations on the folding pathway of human prion protein, J. Biol. Chem. 279 (2004) 18008-18014.

30. S. Liemann, R. Glockshuber, Influence of amino acid substitutions related to inherited human prion diseases on the thermodynamic stability of the cellular prion protein, Biochemistry 38 (1999) 3258-3267.

31. W. Swietnicki, R. B. Petersen, P. Gambetti, W. K. Surewicz, Familial mutations and the thermodynamic stability of the recombinant human prion protein, J. Biol. Chem. 273 (1998) 31048-31052.

32. K. Kaneko, L. Zulianello, M. Scott, C. M. Cooper, A. C. Wallace, T. L. James, F. E. Cohen, S. B. Prusiner, Evidence for protein X binding to a discontinuous epitope on the cellular prion protein during scrapie prion propagation, Proc. Natl. Acad. Sci. USA 94 (1997) 10069-10074.

33. G. C. Telling, M. Scott, J. Mastrianni, R. Gabizon, M. Torchia, F. E. Cohen, S. J. DeArmond, S. B. Prusiner, Prion propagation in mice expressing human and chimeric PrP transgenes implicates the interaction of cellular PrP with another protein, Cell 83 (1995) 79-90.

34. Y. Zhang, W. Swietnicki, M. G. Zagorski, W. K. Surewicz, F. D. Sonnichsen, Solution structure of the E200K variant of human prion protein. Implications for the mechanism of pathogenesis in familial prion diseases, J. Biol. Chem. 275 (2000) 33650-33654.

35. G. Ilc, G. Giachin, M. Jaremko, L. Jaremko, F. Benetti, J. Plavec, I. Zhukov, G. Legname, NMR structure of the human prion protein with the pathological Q212P mutation reveals unique structural features, PloS One 5 (2010) e11715.

36. I. Biljan, G. IlC, G. Giachin, A. Raspadori, I. Zhukov, J. Plavec, G. Legname, Toward the molecular basis of inherited prion diseases: NMR structure of the human prion protein with V210l mutation, J. Mol. Biol. 412 (2011) 660-673.

37. G. S. Baron, B. Caughey, Effect of glycosylphosphatidylinositol anchor-dependent and independent prion protein association with model raft membranes on conversion to the protease-resistant isoform, J. Biol. Chem. 278 (2003) 1488314892.

38. N. R. Deleault, J. C. Geoghegan, K. Nishina, R. Kascsak, R. A. Williamson, Protease-resistant prion protein amplification reconstituted with partially purified substrates and synthetic polyanions, J. Biol. Chem. 280 (2005) 26873-26879.

39. N. R. Deleault, R. W. Lucassen, S. Supattapone, RNA molecules stimulate prion protein conversion, Nature 425 (2003) 717-720.

40. I. Nozaki, T. Hamaguchi, N. Sanjo, M. Noguchi-Shinohara, K. Sakai, Y. Nakamura, T. Sato, T. Kitamoto, H. Mizusawa, F. Moriwaka, Prospective 10-year surveillance of human prion diseases in Japan, Brain 133 (2010) 3043-3057. 
41. S. Shibuya, J. Higuchi, R. W. Shin, J. Tateishi, T. Kitamoto, Codon 219 Lys allele of PRNP is not found in sporadic Creutzfeldt-Jakob disease, Ann. Neurol. 43 (1998) 826-828.

42. I. Biljan, G. Giachin, G. Ilc, I. Zhukov, J. Plavec, G. Legname, Structural basis for the protective effect of the human prion protein carrying the dominant-negative E219K polymorphism, Biochem. J. 446 (2012) 243-251.

43. B. Christen, S. Hornemann, F. F. Damberger, K. Wuthrich, Prion protein NMR structure from tammar wallaby (Macropus eugenii) shows that the beta2-alpha2 loop is modulated by long-range sequence effects, J. Mol. Biol. 389 (2009) 833845.

44. M. Meli, M. Gasset, G. Colombo, Dynamic Diagnosis of Familial Prion Diseases Supports the beta2-alpha2 Loop as a Universal Interference Target, PloS One 6 (2011) e19093.

45. G. Rossetti, X. Cong, R. Caliandro, G. Legname, P. Carloni, Common structural traits across pathogenic mutants of the human prion protein and their implications for familial prion diseases, J. Mol. Biol. 411 (2011) 700-712.

46. M. W. van der Kamp, V. Daggett, Molecular Dynamics as an Approach to Study Prion Protein Misfolding and the Effect of Pathogenic Mutations, Top. Curr. Chem. (2011) 169-197.

47. J. R. Casey, S. Grinstein, J. Orlowski, Sensors and regulators of intracellular pH, Nat. Rev. Mol. Cell Biol. 11 (2010) 50-61.

48. D. O. V. Alonso, S. J. deArmond, F. E. Cohen, V. Daggett, Mapping the early steps in the $\mathrm{pH}$-induced conformational con- version of the prion protein, Proc. Natl. Acad. Sci. USA 98 (2001) 2985-2989.

49. L. Calzolai, R. Zahn, Influence of $\mathrm{pH}$ on NMR Structure and Stability of the Human Prion Protein Globular Domain, J. Biol. Chem. 278 (2003) 35592-35596.

50. M. L. DeMarco, V. Daggett, Molecular Mechanism for Low pH Triggered Misfolding of the Human Prion Protein, Biochemistry 46 (2007) 3045-3054.

51. S. Hornemann, R. Glockshuber, A scrapie-like unfolding intermediate of the prion protein domain $\operatorname{PrP}(121-231)$ induced by acidic pH, Proc. Natl. Acad. Sci. USA 95 (1998) 60106014.

52. E. Langella, R. Improta, V. Barone, Checking the $\mathrm{pH}$-Induced Conformational Transition of Prion Protein by Molecular Dynamics Simulations: Effect of Protonation of Histidine Residues, Biophys. J. 87 (2004) 3623-3632.

53. W. Swietnicki, R. B. Petersen, P. Gambetti, K. Surewicz, pH-dependent Stability and Conformation of the Recombinant Human Prion Protein PrP(90-231), J. Biol. Chem. 272 (1997) 27517-27520.

54. M. W. Van der Kamp, V. Daggett, Influence of $\mathrm{pH}$ on the Human Prion Protein: Insights into the Early Steps of Misfolding, Biophys. J. 99 (2010) 2289-2298.

55. I. Biljan, G. IlC, G. Giachin, J. Plavec, G. Legname, Structural Rearrangements at Physiological pH: Nuclear Magnetic Resonance Insights from the V210I Human Prion Protein Mutant, Biochemistry 51 (2012) 7465-7474.

\section{SUMMARY \\ Structural Studies of Prion Proteins \\ I. Biljan}

Misfolding of normal, cellular prion protein $\left(\mathrm{PrP}^{\mathrm{C}}\right)$ into a pathological form called prion or $\mathrm{Pr} \mathrm{P}^{\mathrm{Sc}}$ is connected with a group of fatal neurodegenerative disorders known as prion diseases or transmissible spongiform encephalopathies. Molecular mechanism of prion formation still remains elusive and structural studies of both forms of PrP are very important for explaining the mechanism of protein misfolding in prion diseases. In some cases, prion diseases are caused by mutations in gene coding for PrP. Structural studies of PrP mutants may provide better understanding of early events of conformational changes during spontaneous formation of prions in inherited prion diseases. This paper gives an overview of the most important results of structural studies of PrPs with the emphasis on studies with PrP mutants performed by high-resolution NMR spectroscopy.

Department of Organic Chemistry, Faculty of Science,

Received October 31, 2012

University of Zagreb, Horvatovac 102A,

10000 Zagreb, Croatia

Accepted December 20, 2012 